\title{
PENGARUH DUA HORMON PERTUMBUHAN DAN TIGA PUPUK KENDANG FORMULA PADA VARIETAS PAPAYA (CARICA PAPAYA L.) DI SIMPANG KIRI, KECAMATAN PELANGIRAN
}

\author{
Tedi Susilo ${ }^{1}$, Mulono Apriyanto² \\ SMK Bakti Agro Kecamatan Pelangiran Kabupaten Indragiri Hilir \\ Fakultas Petanian Unisi \\ Email: mulonoapriyanto71@gmail.com
}

\begin{abstract}
This research was conducted at SMK Bakti Agro Plantation, Pelangiran District to assess the growth and production of papaya solo (Carica papaya L., $2 n=18$ ) in Indragiri Hilir Regency and the effect of giving hormones and manure formula. A separate plot set, consisting of 2 factors with 3 levels of variation each, is used. Main The factor is a hormone represented by gibberellic acid (GA3) and the synthetic auxin Trichloro phenoxi acetic acid (2-4-5-T). The secondary factor is manure which consists of organic matter manure (OF); organic + mineral fertilizer (FOM) and liquid fertilizer (FL). This test is marked with a 9 maintenance (GA3 + FO, GA3 + FOM (organic and mineral fertilizers), GA + FL (liquid fertilizer); 2-4-5-T + FO, 24-5-T + FOM, 2-4-5-T + FL; SH (without hormones) + FO (organic fertilizer); SH + FOM and $\mathrm{SH}+\mathrm{FL}$ ). That carried out on tropical hydromorphic soils that contain lots of iron with a strong water surface. Each treatment was applied to 3 rows of 4 plants. Seen from the application research combination of hormones (GA3 + 2-4-5-T) and organic fertilizer + manure formula stimulates growth and application of hormones (GA3 and 2-4-5-T) in papaya trees possible to reduce planting - the flowering cycle and early setting of fruit.

Keywords: Biomass, flowers, height of plants, number of leaves, planting-flowering.
\end{abstract}

\begin{abstract}
Abstrak
Penelitian ini dilakukan di SMK Bakti Agro Plantation Kecamatan Pelangiran untuk menilai pertumbuhan dan produksi pepaya solo (Carica pepaya L., $2 n=18$ ) di Kabupaten Indragiri Hilir serta pengaruh pemberian hormon dan pupuk kendang rumus. Perangkat plot terpisah, terdiri dari 2 faktor dengan masing-masing 3 tingkat variasi, digunakan. Utama Faktornya adalah hormon yang diwakili oleh asam giberelat (GA3) dan auksin sintetis Trichloro asam asetat fenoxi (2-4-5-T). Faktor sekunder adalah pupuk kandang yang terdiri dari bahan organic pupuk kandang (OF); pupuk organik + mineral (FOM) dan pupuk cair (FL). Tes ini ditandai dengan 9 pemeliharaan (GA3 + FO, GA3 + FOM (pupuk organik dan mineral), GA + $F L$ (pupuk cair); 2-4-5-T + FO, 2-4-5-T + FOM, 2-4-5-T + FL; SH (tanpa hormon) + FO (pupuk organik); $S H+F O M$ dan $S H+F L$ ). Bahwa dilakukan pada tanah hidromorfik tropis yang banyak mengandung besi dengan permukaan air yang kuat. Setiap perlakuan diaplikasikan pada 3 baris dari 4 tanaman. Dilihat dari penelitian aplikasinya kombinasi hormon $(G A 3+2-4-5-T)$ dan pupuk organik + formula pupuk kendang merangsang pertumbuhan dan aplikasi hormon (GA3 dan 2-4-5-T) pada pohon papaya mungkin untuk mengurangi penanaman - siklus pembungaan dan pengaturan awal buah.
\end{abstract}

Kata kunci: Biomassa, bunga, tinggi tanaman, jumlah daun, tanam-berbunga

\section{PENDAhuluan}

Pertanian merupakan tantangan besar bagi perkembangan Indragiri Hilir. Faktanya, sekitar $80 \%$ penduduk mencari nafkah di sana. Mayoritasnya terdiri dari pertanian keluarga kecil yang rentan yang mempraktikkan terutama tanaman pangan
(Abdoulaye et al., 2020). Latihan tanaman industri, sayuran dan buah-buahan juga cukup besar. Di Kabupaten Indragiri, buahbuahan merupakan sumber makanan diperlukan untuk memerangi malnutrisi dan kemiskinan, bahkan jika mereka produksi masih relatif rendah. Memang menurut a 
survei standar konsumsi makanan di Indonesia, konsumsi buah di Indonesia adalah $2 \mathrm{~kg} /$ tahun. Produksi pepaya adalah 13,7 juta ton di seluruh dunia dan 54.664 ton di Indoesia (Hartono, 2020). Dari sudut pandang nutrisi, harus diingat bahwa konsumsi pepaya sangat dianjurkan; umumnya tidak dirawat dengan pestisida. Ini diklasifikasikan sebagai salah satu buah tropis terbaik yang dapat dicerna. Itu bisa dimakan segar, sebagai salad atau sebagai makanan penutup; atau dibuat menjadi jus, sirup, atau selai.

Pepaya tidak terlalu energik karena sifatnya kadar gula rendah (rata-rata 33 kkal versus 55 kkal untuk buah-buahan lainnya). Berkat kekayaan vitamin $\mathrm{C}$, beta karoten $(70 \%)$ dan mineralnya yang sangat luar biasa konsentrasi (tingkat tinggi kalsium, kalium dan magnesium), memberikan kontribusi yang sangat efektif untuk pertahanan dari organisme, dan untuk melawan infeksi. Untuk sebuah proporsi 100 g buah, hingga $85 \%$ asupan nutrisi yang direkomendasikan dipastikan (yaitu $80 \mathrm{mg}$ untuk orang dewasa), yang membantu memenuhi kebutuhan tubuh kebutuhan provitamin (A) sekitar 30\% (caribfruits.cirad.fr/fruits_des_antilles/papay e) (Apriyanto, Mardesci, et al., 2020). Meskipun berbagai keuntungan ini, budaya dihadapkan pada beberapa kendala di Mali yang antara lain hasil, pilihan pemupukan yang memadai, itu ketidakcocokan tanah, kontrol irigasi yang buruk, varietas dan ketahanannya terhadap penyakit (Apriyanto, Fikri, et al., 2020).

Masalah ini hanya bisa diselesaikan dengan pertanian penelitian dan kemajuan teknis, terutama yang berkaitan untuk pemuliaan tanaman dan teknik konservasi (Arpah et al., 2020), (Apriyanto, Marlina, et al., 2020). Selain itu, mengingat melimpahnya kotoran unggas karena perluasan peternakan unggas di pinggiran Koulikoro, tampaknya tepat bagi kami untuk mencari formula berbasis pupuk kendang kotoran unggas menguntungkan untuk produksi pepaya. Inilah konteks studi ini, yang akan dicoba menjawab pertanyaan penelitian berikut: a) melakukan penyemprotan hormon pada pohon pepaya meningkatkannya pertumbuhan? b) melakukan penyemprotan hormon pada papaya pohon memperpendek siklusnya? dan c) apa yang terbaik kombinasi hormon dan formula pupuk kandang yang bisa digunakan pada pepaya?

\section{METODOLOGI PENELITIAN}

\subsection{Cara Penelitian}

Percobaan dilakukan di kebun SMK Bakti Agro Plantation Kecamatan Pelangiran. Daerah ini bercirikan ferruginous tanah hidromorfik tropis dengan hentakan kuat akuifer. Tanah ini memiliki tekstur seperti lumpur, miskin nitrogen dan fosfor, cukup kaya kalium dan sedikit asam. Bahan tanaman Bahan tanaman yang digunakan terdiri dari biji Carica papaya L. (Varietas Solo 8). Benih varietas ini dibeli dari reseller resmi Kementrian Pertanian. Pada awal musim hujan, benih disemai di dalam benih tempat tidur.

\subsection{Hormon dan pupuk digunakan Hormon adalah:}

(i) Asam giberelin (GA3): bersifat bubuk, berwarna keputihan dan dilarutkan dalam alkohol, dan;

(ii) 2-4-5-T Trichloro-phenoxy-acetic acid (24-5 - T) kristal padat larut dalam air.

\section{Pupuk adalah:}

(i) Urea (46\% nitrogen);

(ii) Kalium sulfat ( $50 \%$ kalium);

(iii) Kotoran unggas, dan;

(iv) Pupuk cair dan organik (Aton AZ, Turbo root, Codabor, Coda maxi dan Boramin $\mathrm{Ca}$ ). Pengaturan eksperimental dan ukuran plot

\subsection{Alat}

Percobaan yang digunakan adalah splitplot, dengan 3 kali pengulangan (Marlina et al., 2020); hormon merupakan faktor utama dengan 3 tingkat variasi yang mana merupakan perlakuan utama (asam giberelat (GA3), asam triklorofenoksi-asetat (2-4-5T)), dan kontrol (bebas hormon atau Tidak hormon); formula pupuk kandang diambil sebagai faktor sekunder di 3 tingkat variasi yang merupakan perlakuan sekunder: formula pupuk organik, formula pupuk organik + pupuk kandang mineral, dan formula pupuk cair. Pengulangan dipisahkan oleh lorong seluas $1 \mathrm{~m}$, dibagi lagi menjadi plot utama berukuran $6 \mathrm{~m} \times 6 \mathrm{~m}$ dan plot sekunder berukuran $6 \mathrm{mx} 2 \mathrm{~m}$. Plot uji meliputi area seluas $360 \mathrm{~m}^{2}$, panjang $20 \mathrm{~m}$, dan lebar $18 \mathrm{~m}$.

\subsection{Pengamatan dan pengukuran}

Pengamatan dilakukan setiap dua bulan sekali pada dua tanaman garis tengah dari setiap sub-plot dan terkait dengan pengukuran tinggi tanaman $(\mathrm{cm})$, penghitungan jumlah daun, biomassa daun kering, jumlah bunga, siklus tanamberbunga (jumlah hari antara tanam dan berbunga pada $50 \%$ per petak dasar), jumlah rata-rata dan diameter buah. 
Analisis statistik Hasil dari berbagai observasi menjadi sasaran analisis varians menggunakan perangkat lunak SPSS versi 17.

\section{HASIL DAN PEMBAHASAN}

Semua pengukuran yang dilakukan pada tanaman memungkinkan kami melakukannya menggambar grafik batang pertumbuhan atau perkembangan mereka setelahnya memproses data varians.

Analisis data tinggi tanaman 2 bulan setelah pemulihan Analisis varians data mengungkapkan no perbedaan yang signifikan antara efek hormon. Ini menunjukkan perbedaan yang sangat signifikan antara efek formula pupuk dan efeknya interaksi antara efek hormon. Hasil penelitian menunjukan bahwa tanaman yang menerima pupuk cair GA3 + memperoleh ukuran terbesar dibandingkan yang menerima kombinasi formula GA3 + pupuk organik dan pupuk kandang mineral + pupuk organik. Kombinasi 2- 4-5-T + pupuk organik memberi tanaman lebih besar dari itu diberikan 2-4-5-T dan formula pupuk organik + mineral pupuk. Tanpa hormon, tanaman telah menerima rumus pupuk organik + pupuk kandang mineral yang diperoleh tinggi terbesar dari tanaman yang dirawat dengan formula pupuk cair terlihat pada gambar grafik 1 .

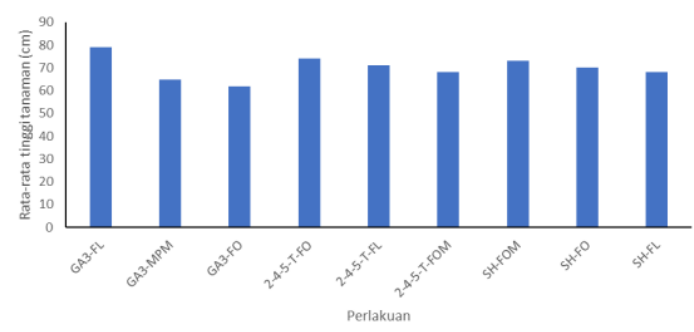

Gambar 1. Pengaruh formula pupuk kandang dan interaksi antar hormon pada tinggi tanaman 2 bulan setelah sembuh. FOM, Pupuk Organik + Pupuk Mineral + Mineral; FO, Pupuk organik; FL, kotoran cair; SH, Tidak Hormon), GA3 (asam Giberrellic), 24-5-T (asam Trichloro-phénoxy-acetic). Kolom dengan huruf yang sama tidak berbeda secara statistik

Analisis data tinggi tanaman 4 bulan setelah pemulihan

Analisis varians menunjukkan perbedaan yang signifikan antara efek hormon dan efek formula mineral. Itu tidak terdeteksi signifikan perbedaan antara efek interaksi hormon dan formula pupuk kandang. Klasifikasi menurut hasil penelitian bahwa tanaman yang menerima GA3 memperoleh ukuran terbesar sedangkan tanpa hormon tanaman terbesar diamati pada petak-petak yang menerima rumus pupuk organik + pupuk kandang mineral tersaji pada gambar 2 dan gambar3.

Gambar 2. Pengaruh formula hormon pada tinggi tanaman 4 bulan setelah sembuh

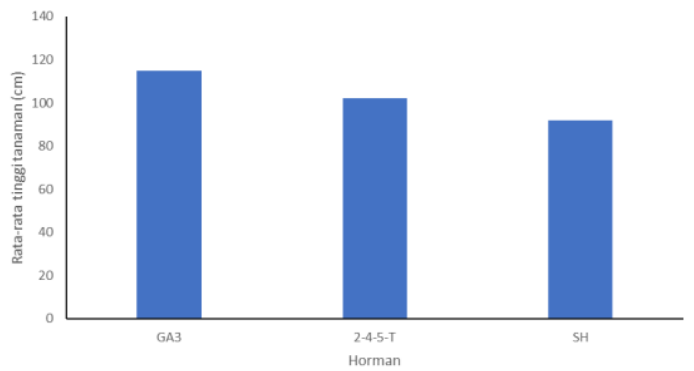

(Gambar 2. Pengaruh formula hormon pada tinggi tanaman 4 bulan setelah sembuh

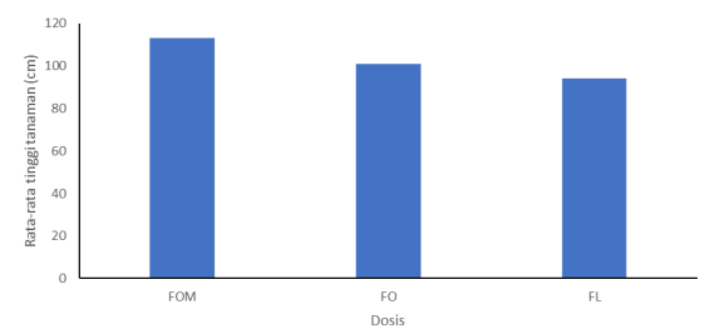

Gambar 3. Pengaruh formula pupuk kandang pada tingg tanaman 4 bulan setelah pemulihan

Analisis data tinggi tanaman 6 bulan setelah pemulihan Analisis varian mengungkapkan tidak hanya signifikan perbedaan antara efek formula pupuk dan orang-orang dari interaksi antara hormon dan pupuk rumus, tetapi juga perbedaan tidak signifikan antara efek hormon. Klasifikasi menurut tes Newman-Keuls memungkinkan untuk memperhatikan tanaman yang menerima GA3 dan formula organic Pupuk + pupuk mineral didapat ukuran yang lebih besar dalam tinggi dibandingkan kombinasi GA3 dan pupuk organik; GA3 dan formula kotoran cair. Tanaman yang menerima 2-4-5-T dan organic pupuk kandang + formula pupuk kandang lebih besar dari yang menerima kombinasi 2-4-5-T dan cairan formula pupuk kandang; 2-4-5-T dan formula pupuk organik. Tanaman tanpa hormon yang mendapat pupuk kandang + kotoran mineral memperoleh ketinggian tertinggi sebagai lawan yang menerima pupuk organik dan / atau cairan pupuk.

Analisis data jumlah daun 2 bulan setelah pemulihan Analisis varians dari data yang diperoleh tidak ditemukan perbedaan yang 
signifikan antara efek hormone dan formula pupuk atau antara efeknya interaksi. Perlu diperhatikan bahwa tanaman memiliki jumlah daun yang sama apapun perawatannya.

Analisis data jumlah daun 4 bulan setelah pemulihan Analisis varian dalam data tidak ditemukan signifikan perbedaan antara efek hormon dan pupuk rumus atau antara efek interaksi mereka. Itu Perlu diperhatikan bahwa tanaman memiliki jumlah yang sama daun apa pun pengobatannya.

Analisis data jumlah daun 6 bulan setelah pemulihan Analisis varians dalam data mengungkapkan hal yang sangat tinggi perbedaan yang signifikan antara efek hormon, efek formula pupuk, dan efek dari interaksi antara hormon dan formula pupuk. Itu klasifikasi, menurut Abdoulaye et al., (2020), dibuat $\mathrm{Hal}$ ini dimungkinkan untuk memperhatikan tanaman yang menerima kombinasi GA3 dan formula pupuk organic mengeluarkan lebih banyak daun dibanding tanaman tanpa hormone dan yang menerima pupuk cair GA3.

Data biomassa daun kering 2 bulan setelah pemulihan Analisis varians dalam data,mengungkapkan signifikan perbedaan antara efek hormon. Itu berhasil mungkin untuk mendeteksi perbedaan yang sangat signifikan antara efek formula pemupukan dan efeknya interaksi dengan hormon. Klasifikasi menurut Abdoulaye et al., (2020) memungkinkan untuk dicatat bahwa file tanaman yang menerima kombinasi GA3 + Liquid formula pupuk kandang dan GA3 + Pupuk Organik dan Mineral formula memberikan jumlah biomassa daun kering tertinggi. Namun, jumlah terendah diperoleh pada tanaman tanpa hormon dan yang menerima GA3 + formula pupuk organic.

Analisis data biomassa daun kering 4 bulan setelah sembuh Analisis varians dalam data mengungkapkan hal yang sangat tinggi perbedaan yang signifikan antara efek hormon dan perbedaan signifikan antara pengaruh interaksi dan formula pemupukan. Itu perbedaan antara efek formula pupuk secara statistik tidak signifikan. Klasifikasi, menurut tes Newman-Keuls, memungkinkan untuk dicatat jumlah terbesar dari biomassa kering diperoleh oleh tanaman menerima kombinasi rumus GA3 + pupuk organik dan formula GA3 + organic pupuk kandang + pupuk kandang mineral. Tanaman yang menerima 2-4-5-T kombinasi memiliki jumlah biomassa kering yang sama. Tanpa hormon, tanaman yang menerima organic pupuk kandang + formula kotoran mineral yang dihasilkan lebih kering biomassa dibandingkan yang menerima kombinasi
$\mathrm{GA} 3$ + formula pupuk cair dan pupuk organik + kotoran mineral; Formula pupuk cair bebas hormone.

Analisis data biomassa daun kering 6 bulan setelahnya pemulihan

Analisis varians dalam data mengungkapkan signifikan perbedaan antara efek formula pupuk dan interaksi antara hormon dan formula pupuk. Ini juga mengungkapkan yang sangat signifikan perbedaan antara efek hormon. Itu klasifikasi menurut Abdoulaye et al., (2020) yang dibuat mungkin untuk mencatat tanaman yang telah menerima kombinasi formula 2-4-5-T + pupuk organik + kotoran mineral dan kotoran 2-4-5-T + cair memberikan jumlah biomassa daun kering tertinggi; mereka diikuti tanaman yang telah menerima kombinasi 2-4-5-T + pupuk organik. Tanaman yang menyediakan biomassa kering terendah diperoleh dari plot itu menerima kombinasi lainnya.

\subsection{Jumlah bunga}

Analisis varians menunjukkan perbedaan yang signifikan antara efek formula pupuk dan efek dari interaksi antara hormon dan formula pupuk. Itu, juga mengungkapkan perbedaan yang sangat signifikan antara efek hormon. Klasifikasi menurut tes Newman-Keuls memungkinkan untuk mencatat tanaman telah menerima kombinasi 2-4-5-T + formula pupuk organik + pupuk kandang mineral dan pupuk kendang 2-4-5-T + pupuk cair memberikan jumlah terbesar bunga-bunga; mereka diikuti dalam urutan menurun oleh tanaman menerima kombinasi 2-4-5-T + pupuk organik, GA3 + pupuk organik dan mineral, GA3 + pupuk organik, GA3 + pupuk kandang dan 245T + cair pupuk. Tanaman dengan jumlah bunga paling sedikit diperoleh dari plot yang tidak menerima hormone.

\subsection{Penanaman - siklus berbunga}

Analisis varians menunjukkan perbedaan yang sangat signifikan hanya antara efek hormon. Signifikasi data menunjukan bahwa file kontribusi hormon mengurangi vegetasi siklus tanaman secara mandiri dari pemupukan rumus.

\subsection{Jumlah dan diameter buah}

Kami mencatat pembentukan buah pada tanaman yang memiliki menerima hormon $\mathrm{GA} 3$ + pupuk organik + mineral pupuk kandang dan 2-4-5-T + pupuk organik + pupuk mineral. Tanaman yang menerima AG3 tampaknya menghasilkan lebih banyak buah dibandingkan yang menerima 2-4-5-T (26 versus 19). Tanaman yang menerima AG3 tampaknya menghasilkan buah 
berdiameter lebih besar dibandingkan yang diperoleh pada $2-4-5-\mathrm{T}(4,2 \mathrm{~cm}$ versus 3,2 $\mathrm{cm}$ ).

\subsection{Pembahasan}

Hasil yang diperoleh dari percobaan ini menunjukkan bahwa tanaman yang menerima GA3 + formula organic pupuk kandang + pupuk mineral dan yang menerima 2-4-5-T + formula pupuk organik + pupuk kandang mineral memiliki pemangkasan terbesar, jumlah biomassa kering tertinggi,jumlah bunga tertinggi, tanam-berbunga terpendek siklus dan produksi buah paling awal. Hasil kami menguatkan dengan studi yang dilakukan pada perilaku tanaman kacang-kacangan, Phaseolus vulgaris (Buss et al., 2011), di bawah pengaruh hormon pertumbuhan: auksin dan asam giberelat.

Hormon pertumbuhan berpengaruh pada pertumbuhan tanaman lebih cepat, selain menghasilkan buah tanpa biji beberapa aplikasi lain (Apriyanto, Sutardi, Supriyanto, et al., 2017). Tanaman di bawah pengaruh mereka tidak proporsional dan sangat ekstrim besar karena hormon bekerja secara khusus di akar, batang dan perkembangbiakan daun. Namun, untuk mengamati fenomena ini, itu perlu untuk tumbuh tanaman yang cukup untuk eksperimen agar valid secara statistik.

Selain itu, masa pertumbuhannya harus cukup lama untuk dilihat perbedaan utama dan semua tanaman harus menyerap jumlah hormon yang cukup (Apriyanto, Sutardi, Harmayani, et al., 2017; Apriyanto, Sutardi, Supriyanto, et al., 2017). Menurut hipotesis, tanaman dirawat dengan auksin konsentrasi $1 \times 10$ - $4 \mathrm{~mol} / \mathrm{L}$, dan tersebut diolah dengan asam giberelat dengan konsentrasi 500 ppm memiliki pertumbuhan yang lebih cepat.

\section{KESIMPULAN DAN SARAN}

\subsection{Kesimpulan}

Dari hasil yang didapat, diameter tanaman lebih besar diperoleh di tingkat petak yang menerima formula pupuk organik + pupuk kandang dan kotoran organic (Riono \& Apriyanto, 2020). Tanaman yang menerima GA3 + organic formula pupuk + pupuk mineral yang dihasilkan paling tinggi jumlah daun dibandingkan yang menerima lainnya kombinasi GA3 2-4-5-T yang tidak merangsang daun produksi di pabrik. Tanpa hormon, tanaman yang mendapat formula pupuk organik memiliki jumlah daun terbanyak dibandingkan yang menerima pupuk organik + pupuk mineral dan pupuk cair.
Jumlah biomassa kering terbesar diperoleh oleh PT tanaman yang menerima kombinasi 2-4-5-T + formulasi pupuk organik + pupuk kandang mineral dan 2-Formulasi pupuk kandang 4-5-T +. Jumlah kering terendah biomassa disediakan oleh tanaman yang menerima kombinasi formula pupuk organik GA3 + dan GA3 + formula kotoran cair. Penambahan hormon berkurang siklus vegetasi tanaman terlepas dari formula pemupukan. Pembentukan buah diperoleh pada tanaman yang menerima pupuk organik hormon GA3 ++ pupuk kandang mineral dan 2-4-5-T + pupuk organik + kotoran mineral. Tanaman yang menerima GA3 tampaknya menghasilkan lebih banyak buah daripada yang menerima 2-4-5-T (26 versus 19). Tanaman yang menerima GA3 tampaknya menyediakan buah berdiameter lebih besar dari yang diperoleh 2-4-5-T (4,2 $\mathrm{cm}$ versus $3,2 \mathrm{~cm}$ ).

\section{DAFTAR PUSTAKA}

[1] Abdoulaye, S., Mamourou, T. B., \& Tassiou, Y. (2020). Effects of two growth hormones and three manure formulas on a variety of papaya ( Carica papaya $L$.) in the Sudano-Sahelian zone of Mali. African Journal of Agricultural Research, 16(12), 1631-1639. https://doi.org/10.5897/AJAR2020.15071

[2] Apriyanto, M., Fikri, K. M. S. N. S., Siregar, V. A., \& Azhar, A. (2020). Penyuluhan Tentang Peremajaan Kelapa Sawit dan Legalitas Lahan Di Kecamatan Kempas Kabupaten Indragiri Hilir. ARBITRASE: Journal of Economics and Accounting, 1(1), 1-6.

[3] Apriyanto, M., Mardesci, H., \& Rujiah, R. (2020). PERUBAHAN ASAM ASETAT, TOTAL POLIFENOL DAN WARNA BIJI KAKAO ASALAN SELAMA FERMENTASI. Jurnal Industri Hasil Perkebunan, 15(1), 10-16.

[4] Apriyanto, M., Marlina, \& Arpah, M. (2020). Perbanyakan Tanaman Secara Vegetatif Di Desa Pekan Kamis Kelurahan Tembilahan Barat. Celebes Abdimas: Jurnal Pengabdian Kepada Masyarakat, 2(1), 42-46.

[5] Apriyanto, M., Sutardi, Harmayani, E., \& Supriyanto. (2017). Amino acid analysis of cocoa fermented by High Performeance Liquid Chromatography (HPLC). Asian Journal of Dairy and Food Research, 36(2), 156-160.

[6] Apriyanto, M., Sutardi, S., Supriyanto, S., \& Harmayani, E. (2017). Fermentasi Biji Kakao Kering Menggunakan Saccharomyces cerevisiae, Lactobacillus 
lactis, dan Acetobacter aceti. AgriTECH, 37(3), 302-311.

[7] Arpah, M., Marlina, \& Apriyanto, M. (2020). Effect Of Grant Palm Oil Ash To The Growth And Production Of Two Corn Varieties (Zea Mays L) In Peatland. Int. J. Sci. Technol. Res, 9(4), 990-993.

[8] Buss, D. S., Dias, G. B., Santos, M. P., Ventura, J. A., Machado, P., \& Fernandes, B. (2011). Oxidative Stress Defence Response of Carica papaya Challenged by Nitric Oxide, Papaya meleira virus and Saccharomyces cerevisiae. 55-64.

[9] Hartono. (2020). Kabupaten Indragiri Hilir Dalam Angka 2020. In BPS Kabupaten Indragiri Hilir.

[10] Marlina, Sari, I., Yusuf, E. Y., Riono, Y., \& Apriyanto, M. (2020). Utilization Of Industrial Waste Pulp And Palm Oil On Growth And Results Of Corn (Zea Mays L) On Peat. Int. J. Sci. Technol. Res, 9(1), 109-112.

[11] Riono, Y., \& Apriyanto, M. (2020). PEMANFAATAN ABU SEKAM PADI DALAM INOVASI PEMUPUKAN KACANG HIJAU (Vigna radiate L) DI LAHAN GAMBUT. Selodang Mayang: Jurnal Ilmiah Badan Perencanaan Pembangunan Daerah Kabupaten Indragiri Hilir, 6(2), 60. https://doi.org/10.47521/selodangmayan g.v6i2.164 